Article

\title{
Antioxidant Activities of Alkyl Substituted Pyrazine Derivatives of Chalcones-In Vitro and In Silico Study
}

\author{
Višnja Stepanić ${ }^{1, *(D)}$, Mario Matijašić ${ }^{2}(D)$ Tea Horvat ${ }^{1}$, Donatella Verbanac ${ }^{2,3}$, \\ Marta Kučerová-Chlupáčová ${ }^{4}$ (D), Luciano Saso ${ }^{5}$ (D) and Neven Žarković ${ }^{1, *}$ \\ 1 Division of Molecular Medicine, Ruđer Bošković Institute, Bijenička cesta 54, HR-10000 Zagreb, Croatia; \\ Tea.Horvat@irb.hr \\ 2 Department for Intercellular Communication, Centre for Translational and Clinical Research and Croatian \\ Centre of Excellence for Reproductive and Regenerative Medicine, School of Medicine, University of Zagreb, \\ Šalata 2, HR-10000 Zagreb, Croatia; mario.matijasic@mef.hr (M.M.); dverbanac@pharma.hr (D.V.) \\ 3 Department of Medical Biochemistry and Haematology, Faculty of Pharmacy and Biochemistry, University \\ of Zagreb, Domagojeva 2, HR-10000 Zagreb, Croatia \\ 4 Department of Pharmaceutical Chemistry and Pharmaceutical Analysis, Faculty of Pharmacy, \\ Charles University, Heyrovského 1203, 50005 Hradec Králové, Czech Republic; kucerom@faf.cuni.cz \\ 5 Department of Physiology and Pharmacology Vittorio Erspamer, Sapienza University, P.le Aldo Moro 5, \\ 00185 Rome, Italy; luciano.saso@uniroma1.it \\ * Correspondence: stepanic@irb.hr (V.S.); zarkovic@irb.hr (N.Ž.); \\ Tel.: +385-1-457-1248 (V.S.); +385-1-457-1234 (N.Ž.)
}

Received: 5 March 2019; Accepted: 2 April 2019; Published: 5 April 2019

check for updates

\begin{abstract}
Chalcones are polyphenolic secondary metabolites of plants, many of which have antioxidant activity. Herein, a set of 26 synthetic chalcone derivatives with alkyl substituted pyrazine heterocycle $\mathrm{A}$ and four types of the monophenolic ring $\mathrm{B}$, were evaluated for the potential radical scavenging and antioxidant cellular capacity influencing the growth of cells exposed to $\mathrm{H}_{2} \mathrm{O}_{2}$. Before that, compounds were screened for cytotoxicity on THP- 1 and HepG2 cell lines. Most of them were not cytotoxic in an overnight MTS assay. However, three of them, 4a, 4c and 4e showed 1,1-diphenyl-2-picrylhydrazyl $(\mathrm{DPPH} \bullet$ ) radical scavenging activity, through single electron transfer followed by a proton transfer (SET-PT) mechanism as revealed by density functional theory (DFT) modeling. DFT modeling of radical scavenging mechanisms was done at the SMD//(U)M052X/6-311++G $\mathrm{G}^{* *}$ level. The in vitro effects of $4 \mathrm{a}, 4 \mathrm{c}$ and $4 \mathrm{e}$ on the growth of THP- 1 cells during four days pre- or post-treatment with $\mathrm{H}_{2} \mathrm{O}_{2}$ were examined daily with the trypan blue exclusion assay. Their various cellular effects reflect differences in their radical scavenging capacity and molecular lipophilicity (clogP) and depend upon the cellular redox status. The applied simple in vitro-in silico screening cascade enables fast identification and initial characterization of potent radical scavengers.
\end{abstract}

Keywords: antioxidant; chalcone-like; DFT; in silico; in vitro; pyrazine; radical scavenging

\section{Introduction}

Chalcones are molecules containing a 1,3-diphenylprop-2-en-1-one fragment (Figure 1). They are natural products from the group of flavonoids. Plenty of chalcones have been isolated from natural plant sources [1]. However, numerous synthetic chalcone derivatives with various substitutions at the benzene rings or with heterocyclic analogs have also been prepared in laboratories [2]. From the synthetic aspect, the advantage of chalcones is the structural versatility generated by relatively simple synthetic procedures [2-4]. 
<smiles>COc1cc(O)c(O)c(C(=O)/C=C/c2ccc(O)cc2)c1O</smiles><smiles>CC(C)=CCc1c(O)ccc(C(=O)/C=C/c2ccc(O)cc2)c1O</smiles><smiles>[R]Oc1cc(O)cc(O)c1C(=O)/C=C/c1ccc(O)cc1</smiles>

naringenin chalcone $\mathrm{R}=\mathrm{H}$ isosalipurpuroside $\mathrm{R}=\mathrm{Glc}$<smiles>O=C(/C=C/c1ccc(O)c(O)c1)c1ccc(O)cc1O</smiles>

butein

Figure 1. Natural chalcone antioxidants [1]. The 1,3-diphenylprop-2-en-1-one fragment is marked red and the atom numbering used for all studied compounds is labelled.

Herein, we have considered chalcone-like compounds with non-substituted or $4^{\prime}$-alkyl substituted pyrazine heterocycle at the place of benzene ring A (Figure 1, Table 1). Some biological activities of these synthetic derivatives have already been described. Chalcones and their various heterocyclic analogues exert modulatory effects on different molecular targets depending on the aromatic system types and the substitution pattern [4,5]. The pyrazine analogues of chalcones have been screened for antimicrobial and antifungal activity, but the derivatives considered here have shown no significant anti-infective effects [6-8]. Antiproliferative activity of chalcones has also been tested on various cancer cell lines [9]. Chalcones exert cytotoxic effects on various cancer cell lines and their use as antitumor agents with various molecular mechanisms of action, has been discussed in several recently published reviews $[5,10,11]$. However, many chalcones with significant pharmacological effects are not toxic to non-tumorous cells and for that reason chalcones are suggested for cancer chemoprevention $[1,12]$. Cancer chemopreventative activity has been demonstrated for natural chalcones, e.g., xanthohumol (Humulus lupulus, Cannabaceae), naringenin chalcone and its glucoside isosalipurpuroside (Helichrysum maracandicum, Asteraceae), isobavachalcone (Angelica keiskei, Apiaceae), as well as for various synthetic hydroxylated and methoxylated chalcones (Figure 1) [13-15]. Chemopreventative effects of chalcones have been recognized in respect to their interference with cellular mechanisms involved in mutagenesis and/or the repair of damaged DNA, as well as with chalcone related increases in phase 2 metabolic enzyme activity [16].

Biological effects of chalcones have also been ascribed to their antioxidative activities [18]. Chalcones exert indirect and direct redox activities. They are inhibitors of aldose reductase ALR2, an enzyme with antioxidative and anti-inflammatory effects [19-21]. There are also chalcones with direct radical scavenging (RS) activities [18,22]. The direct RS activity of natural chalcones such as prenylated xanthohumol [15], non-prenylated butein [15,23] or various licorice chalcones is well-documented [24]. The presence of free hydroxyl groups (at C-2' in the ring A and a catechol group in the ring B) and the $\alpha, \beta$-double bond in the linker are considered important structural features for efficient antiradical activity of chalcones [15].

The aim of our study was to explore the antioxidant potential associated with the RS mechanism for the set of synthetic pyrazine analogues of chalcones [19,25]. Their antioxidant activities were measured in vitro through direct reaction with a 1,1-diphenyl-2-picrylhydrazyl radical (DPPH•) and additionally in the THP-1 cellular assay treated with hydrogen peroxide $\left(\mathrm{H}_{2} \mathrm{O}_{2}\right)$. The RS mechanism was characterized by performing quantum-chemical density functional theory (DFT) modeling. The observed difference in antioxidant cellular activity of good radical scavengers was ascribed to differences in their RS capacity and molecular lipophilicity. 
Table 1. The pyrazine analogues of chalcones tested for cytotoxicity against cell lines HepG2 and THP-1 $\left(\mathrm{IC}_{50}(\mu \mathrm{M})\right)$ and on DPPH• radical scavenging (RS) activity $\left(\mathrm{IC}_{50}(\mu \mathrm{M})\right)$. Their lipophilicity was estimated in silico.

\begin{tabular}{|c|c|c|c|c|c|c|c|}
\hline Compound & $x$ & R1 & R2 & HepG2 & THP-1 & $\mathrm{DPPH}{ }^{1}$ & $\operatorname{clog} P^{2}$ \\
\hline 1 & $\mathrm{CH}$ & $\mathrm{H}$ & $2-\mathrm{OH}$ & $>100$ & 70 & $>1000$ & 2.96 \\
\hline 1a & $\mathrm{N}$ & $\mathrm{H}$ & $2-\mathrm{OH}$ & $>100$ & 40 & $>1000$ & 1.01 \\
\hline $1 b$ & $\mathrm{~N}$ & propyl & $2-\mathrm{OH}$ & $>100$ & $>100$ & & 2.28 \\
\hline $1 \mathrm{c}$ & $\mathrm{N}$ & isopropyl & $2-\mathrm{OH}$ & $>100$ & 96 & $>1000$ & 2.25 \\
\hline $1 d$ & $\mathrm{~N}$ & butyl & $2-\mathrm{OH}$ & 86 & 27 & $>1000$ & 2.73 \\
\hline $1 \mathrm{e}$ & $\mathrm{N}$ & isobutyl & $2-\mathrm{OH}$ & $>100$ & 94 & & 2.50 \\
\hline 1f & $\mathrm{N}$ & tert-butyl & $2-\mathrm{OH}$ & $>100$ & $>100$ & & 2.65 \\
\hline 2 & $\mathrm{CH}$ & $\mathrm{H}$ & $3-\mathrm{OH}$ & $>100$ & 51 & $>1000$ & 2.96 \\
\hline $2 a$ & $\mathrm{~N}$ & $\mathrm{H}$ & $3-\mathrm{OH}$ & 100 & 50 & $>1000$ & 1.01 \\
\hline $2 b$ & $\mathrm{~N}$ & propyl & $3-\mathrm{OH}$ & $>100$ & 48 & & 2.28 \\
\hline $2 c$ & $\mathrm{~N}$ & isopropyl & $3-\mathrm{OH}$ & 97 & 83 & $>1000$ & 2.25 \\
\hline $2 d$ & $\mathrm{~N}$ & butyl & $3-\mathrm{OH}$ & $>100$ & 67 & $>1000$ & 2.73 \\
\hline $2 \mathrm{e}$ & $\mathrm{N}$ & isobutyl & $3-\mathrm{OH}$ & $>100$ & $>100$ & & 2.50 \\
\hline $2 f$ & $\mathrm{~N}$ & tert-butyl & $3-\mathrm{OH}$ & $>100$ & $>100$ & & 2.65 \\
\hline 3 & $\mathrm{CH}$ & $\mathrm{H}$ & $4-\mathrm{OH}$ & $>100$ & $>100$ & $>1000$ & 2.96 \\
\hline $3 a$ & $\mathrm{~N}$ & $\mathrm{H}$ & $4-\mathrm{OH}$ & $>100$ & 97 & $>1000$ & 1.01 \\
\hline $3 b$ & $\mathrm{~N}$ & propyl & $4-\mathrm{OH}$ & $>100$ & 94 & & 2.28 \\
\hline $3 c$ & $\mathrm{~N}$ & isopropyl & $4-\mathrm{OH}$ & $>100$ & 78 & $>1000$ & 2.25 \\
\hline $3 d$ & $\mathrm{~N}$ & butyl & $4-\mathrm{OH}$ & $>100$ & 83 & $>1000$ & 2.73 \\
\hline $3 e$ & $\mathrm{~N}$ & isobutyl & $4-\mathrm{OH}$ & $>100$ & $>100$ & & 2.50 \\
\hline $3 f$ & $\mathrm{~N}$ & tert- butyl & $4-\mathrm{OH}$ & $>100$ & $>100$ & & 2.65 \\
\hline 4 & $\mathrm{CH}$ & $\mathrm{H}$ & $3-\mathrm{OCH}_{3}, 4-\mathrm{OH}$ & $>100$ & $>100$ & & 2.89 \\
\hline $4 a$ & $\mathrm{~N}$ & $\mathrm{H}$ & $3-\mathrm{OCH}_{3}, 4-\mathrm{OH}$ & $>100$ & $>100$ & 186 & 0.94 \\
\hline $4 c$ & $\mathrm{~N}$ & isopropyl & $3-\mathrm{OCH}_{3}, 4-\mathrm{OH}$ & $>100$ & $>100$ & 39 & 2.18 \\
\hline $4 \mathrm{e}$ & $\mathrm{N}$ & isobutyl & $3-\mathrm{OCH}_{3}, 4-\mathrm{OH}$ & $>100$ & $>100$ & 46 & 2.43 \\
\hline $4 f$ & $\mathrm{~N}$ & tert-butyl & $3-\mathrm{OCH}_{3}, 4-\mathrm{OH}$ & $>100$ & 36 & & 2.58 \\
\hline
\end{tabular}

${ }^{1}$ The $\mathrm{IC}_{50}$ for vitamin $\mathrm{C}$ is $15 \mu \mathrm{M} .{ }^{2}$ Values of molecular lipophilicity (clogP) were calculated by DataWarrior [17].

\section{Materials and Methods}

\subsection{Studied Compounds}

All studied chalcone and chalcone-like compounds were synthesized previously according to the cited references [6-8,19]. The structural characteristics of all compounds (melting points, IR and NMR data) are available: for compounds 1, 2, 3 and 4 in the supplementary material of Reference [19], 1a, 1b, 1d, 1e, 1f, 3a, 3b, 3d, 3e, 3f, 4a, 4e and 4f in Reference [6], 2a, 2b, 2d, 2e and $2 \mathrm{f}$ in Reference [7] and 1c, 2c, $3 c$ and $4 c$ in Reference [8]. The compounds were dissolved in dimethyl sulfoxide (DMSO).

\subsection{Cell Lines}

Adherent liver hepatocellular carcinoma cell line HepG2 (ATCC, HB-8065) and human acute monocytic leukemia cell line in suspension THP-1 (ATCC, TIB-202) were purchased from American Type Culture Collection (ATCC, Manassas, VA, USA). Cell lines were maintained in complete DMEM/F12 medium (Sigma, D8437, St. Louis, MO, USA) and complete RPMI1640 (Sigma, R7388, St. Louis, MO, USA) respectively, supplemented with $10 \%$ Fetal Calf Serum (FCS, Sigma, F7524, St. Louis, MO, USA) at $37^{\circ} \mathrm{C}$ in $5 \% \mathrm{CO}_{2}$ atmosphere. 


\subsection{Cytotoxic Activity}

A cytotoxicity assay was performed using MTS CellTiter 96 AQueous One Solution Cell Proliferation Assay (Promega, G3580, Madison, WI, USA) [26]. Double dilutions of compounds were prepared in the concentration range of $100-0.2 \mu \mathrm{M}$ within microplate wells. In each well, $5 \times 10^{4}$ cells were added and the plates were incubated overnight at $37^{\circ} \mathrm{C}$ in $5 \% \mathrm{CO}_{2}$ atmosphere. Following this, $10 \mu \mathrm{L}$ of MTS (3-(4,5-dimethylthiazol-2-yl)-5-(3-carboxymethoxyphenyl)-2-(4-sulfophenyl)-2H -tetrazolium) reagent was dispensed per well and the plates were incubated for $1-6 \mathrm{~h}$ at $37^{\circ} \mathrm{C}$ in $5 \% \mathrm{CO}_{2}$ atmosphere. Control wells consisted of media only (blank) or cells with $1 \%$ DMSO added (control). The absorbance was recorded at $490 \mathrm{~nm}$ using a Wallac Victor2 microplate reader (PerkinElmer, Waltham, MA, USA). Results were analyzed in GraphPad Prism software (GraphPad Software, San Diego, CA, USA).

\subsection{DPPH• Radical Scavenging Assay}

The DPPH (1,1-diphenyl-2-picrylhydrazyl, Sigma, D9132, St. Louis, MO, USA) method was used to determine the RS activity of compounds [27]. Vitamin C (Acros Organics, Geel, Belgium) was used as a standard antioxidant control and was prepared in the same way as tested compounds. Dilutions of tested compounds and vitamin $C$ were prepared in a final concentration range of $1 \mathrm{mM}-0.01 \mu \mathrm{M}$. One milliliter of compound solution was added to $1 \mathrm{~mL}$ of freshly prepared DPPH• solution $(3.9 \mathrm{mg} / 50 \mathrm{~mL}$ ethanol; final concentration of $100 \mu \mathrm{M})$ and the reaction mixture was incubated in the dark at room temperature for $30 \mathrm{~min}$. Absorbance was recorded at $540 \mathrm{~nm}$ using a 96-well Wallac Victor2 plate reader. Neutralization of DPPH• radical by a compound was calculated according to the following formula:

$$
\text { RS activity }(\%)=\left[\left(\mathrm{A}_{0}-\mathrm{A}_{1}\right) / \mathrm{A}_{0}\right] \times 100
$$

where $A_{0} / A_{1}$ is the control/sample absorbance. The results were averages of three measurements. The $\mathrm{IC}_{50}$ value was calculated using GraphPad Prism software (GraphPad Software, San Diego, CA, USA).

\subsection{Effects of Compounds on the Growth of THP-1 Cells Treated with $\mathrm{H}_{2} \mathrm{O}_{2}$}

The substances without cytotoxic effects and with $\mathrm{RS}$ activity were tested for antioxidant potential at the cellular level using THP- 1 cells treated by $\mathrm{H}_{2} \mathrm{O}_{2}$ [28]. The cells were exposed to the $\mathrm{IC}_{50}$ concentrations of the compounds determined by the DPPH• assay. Compounds were applied $30 \mathrm{~min}$ either before or after exposure to $5 \mathrm{mM}$ of $\mathrm{H}_{2} \mathrm{O}_{2}$, which is equivalent to the cytotoxic $\mathrm{ED}_{50}$ dose of $\mathrm{H}_{2} \mathrm{O}_{2}$ for the THP-1 cells [28]. The cell growth was analyzed every $24 \mathrm{~h}$, via the trypan blue exclusion assay using a Bürker-Türk hemocytometer (Brand GMBH + CO KG, Wertheim, Germany), during a 4-day period. All assays were carried out in triplicates. The comparison of mean values was done by the two-tailed Student's $t$-test.

\subsection{In Silico Methods}

\subsubsection{Predictions of Physicochemical and ADME/Tox Properties}

Physicochemical and ADME/Tox (Absorption, Distribution, Metabolism and Excretion / Toxicity) parameters were predicted by the algorithms DataWarrior [17] and SwissADME [29]. Inputs for both algorithms were SMILES (simplified molecular-input line-entry system) (Supplementary Table S1).

\subsubsection{Molecular Similarity}

The MACCS fingerprint generation and molecular similarity clustering using binary distance were done by $\mathrm{R}$ packages $r c d k$ and factoextra, respectively [30,31]. 


\subsubsection{DFT Calculations}

The gas-phase $(\mathrm{g})$ reaction parameters: bond dissociation enthalpy (BDE), ionization potential (IP), acidity and electron transfer enthalpy (ETE), as well as their aqueous (aq) free energy (FE) counterparts $\mathrm{BDFE}_{\mathrm{aq}}, \mathrm{IFE}_{\mathrm{aq}}, \mathrm{pK}_{\mathrm{a}}$, and ETFE $\mathrm{aq}$, respectively, were calculated by using thermochemical cycles [32] along with the DFT model (U)M052X/6-311++G ${ }^{* *}$ implemented in Gaussian 09 [33,34]. Equilibrium geometries in neutral and anionic closed-shell as well as neutral mono-radical and radical cation open-shell doublet ground electronic states, were optimized in the gas phase. The minima were confirmed by no imaginary vibrational frequencies. Calculations were done with the compounds in E-configuration [6-8,19]. The free energies of hydration $\Delta G^{*}$ hyd were determined at the gas phase geometries by using the universal continuum solvation model SMD [35].

\section{Results and Discussion}

\subsection{In Vitro Cytotoxicity}

The cytotoxic effects of 26 compounds were evaluated by using the MTS test which has been run as a part of routine safety compound profiling [26,36]. The compounds (applied in concentrations up to $100 \mu \mathrm{M}$ overnight) showed no considerable effects on cellular metabolism and viability of HepG2 and THP-1 cells (Table 1). None of compounds were cytotoxic against HepG2 cells. In regard to THP-1 cells, stronger cytotoxicity was detected only for the two compounds: the 2-OH substituted derivate $1 \mathrm{~d}$ and the $3-\mathrm{OCH}_{3}, 4-\mathrm{OH}$ substituted derivate $4 \mathrm{f}$, for which the $\mathrm{IC}_{50}$ values were $27 \mu \mathrm{M}$ and $36 \mu \mathrm{M}$, respectively. In addition, compounds with single 2- or 3-OH group in the ring B showed, in average, somewhat stronger cytotoxicity as compared with the 4-OH analogues (Table 1) [37].

However, some of the studied compounds have been determined to exert cytotoxic effects during a longer incubation period (Figure 2) and/or against another cancer cell lines. For example, the chalcone 3 had significant cytotoxicity against cell lines A549, PC3, MCF-7, HT-29 and WRL68 [9]. Many chalcone analogues with heteroaryl A or B ring(s) (e.g., indole or quinolone analogues) have also been reported to exhibit potent growth inhibitory activity on cancer cell lines [5,10].
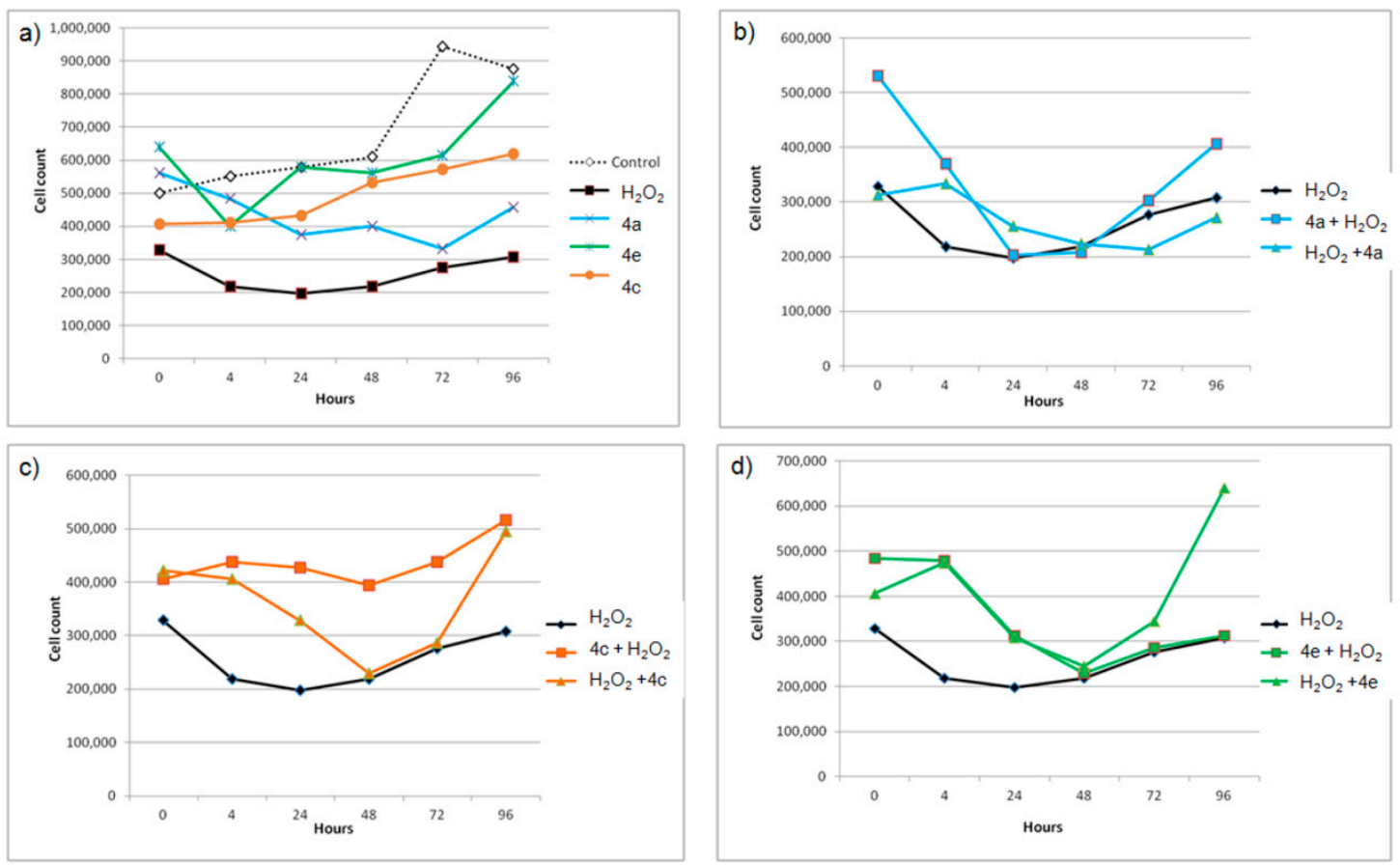

Figure 2. (a) The effects of the radical scavengers $4 \mathrm{a}, 4 \mathrm{c}$ and $4 \mathrm{e}$ and the oxidant $\mathrm{H}_{2} \mathrm{O}_{2}$ on the growth of THP- 1 cells cultured for $96 \mathrm{~h}$; (b-d) the effects of the compounds given $30 \mathrm{~min}$ either before (compound $\left.+\mathrm{H}_{2} \mathrm{O}_{2}\right)$ or after $\left(\mathrm{H}_{2} \mathrm{O}_{2}+\right.$ compound) $\mathrm{H}_{2} \mathrm{O}_{2}$ on the THP- 1 cells. 


\subsection{In Vitro and in Silico Radical Scavenging Analysis}

The various types of redox activity of the studied pyrazine chalcone derivatives have been demonstrated so far [6,19]. Some of them inhibited the catalytic activity of aldose reductase ALR2. The pyrazine derivatives $2 a$ and $3 a$ showed moderate ALR2 inhibition activity. Regarding the corresponding chalcones, only 3 had comparable ALR2 inhibition. Neither chalcones nor their pyrazine analogues with 2-OH or 3- $\mathrm{OCH}_{3}, 4-\mathrm{OH}$ substitutions showed this activity. The 2-OH (series 1 ) and 4-OH (series 3) substituted compounds with a $4^{\prime}$-alkylated pyrazine ring A (Table 1) were also found to impair the photosynthetic electron transport system in plants in the study of their herbicide activity, which was conducted since the pyrazine chalcone derivatives have common structural features with the cinnamoyl pyrazine plant growth inhibitors [6].

Chalcones have also been tested in various RS assays [19,38]. When tested in the assay of styrene auto-oxidation under oxygen atmosphere at $50{ }^{\circ} \mathrm{C}$ initiated by azo-bis-isobutyronitrile, $1 \mathrm{a}$, 3a and 4a showed significant RS activity comparable to or even greater than that of the corresponding para-coumaric acid fragment [38]. Antioxidative activity of chalcones 3 and 4 and their pyrazine analogues $3 a$ and $4 a$, respectively, have been measured in the DPPH• assay and the compounds with the guaiacyl-like ring B (series 4) were determined to have moderate RS capacity [19]. In our study, the DPPH• RS activity was measured for other synthesized derivatives as well (Table 1).

Among all tested compounds, only the guaiacyl-substituted derivatives $4 \mathrm{a}, 4 \mathrm{c}$ and $4 \mathrm{e}$ have displayed DPPH• RS potential with $\mathrm{IC}_{50}$ values of $186 \mu \mathrm{M}, 39 \mu \mathrm{M}$ and $46 \mu \mathrm{M}$, respectively (Table 1). They were weaker DPPH• radical scavengers than the reference vitamin $\mathrm{C}$ which has an $\mathrm{IC}_{50}$ value of $15 \mu \mathrm{M}$. It is well-known that phenolic compounds with high RS activity generally have a catechol fragment [32,39-41]. The elimination of one of the catecholic $\mathrm{OH}$ groups e.g., by methylation, diminishes the RS capacity of polyphenols [40].

The obtained DPPH• RS data were interpreted and the underlying RS mechanism of the guaiacyl-substituted derivatives was determined by applying quantum-chemical modeling (Table 2). Three mechanisms have been proposed for RS by phenolic compounds [32]. It has been proposed that neutral phenolic compounds may scavenge free radicals by donating an $\mathrm{H}$-atom in a one-step hydrogen-atom transfer (HAT) mechanism which is described by the O-H BDE parameter. In a simple model designed for the estimation of relative RS capacities, the parameter BDE is defined as a difference between a sum of enthalpies of the phenoxy radical and hydrogen atom products and an enthalpy of a neutral phenolic reactant [32]. Another proposed RS mechanism for neutral phenols is a two-step process composed of a single electron transfer followed by fast proton transfer from the positively charged radical intermediate (SET-PT). The first step is described by the ionization potential (IP) of a phenolic molecule. In the third proposed RS mechanism, the two-step sequential proton loss electron transfer (SPLET), following the first step of deprotonation of a phenolic group (described by its acidity constant), an intermediate anion donates an electron with capacity described by the parameter ET(F)E [32]. Assuming that $4^{\prime}$-alkyl substituents do not considerably influence the RS properties of the free -OH group in the ring B [41], the parameters were calculated for the compounds with an unsubstituted ring A (a-compounds) and their chalcone analogs (Table 2).

By comparing the parameter values with those of the good radical scavengers, quercetin and vitamin C, only compounds with the guaiacyl group (series 4 ) are predicted to have moderate RS activity. This has been in agreement with the in vitro results (Table 1). Since the prediction is based on the comparison of the IP $\mathrm{g}$ and $\mathrm{IFE}_{\mathrm{aq}}$ values, the associated RS mechanism of these derivatives has

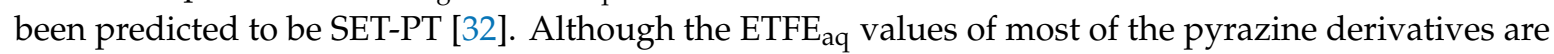
comparable with those of reference compounds (Table 2), since they are weak acids $\left(\mathrm{pK}_{\mathrm{a}}>10.0\right.$ except for 1a, Table 2), SPLET is not expected to be their dominant RS mechanisms. If it were an important RS mechanism, then the compounds with a 3-OH group would have also shown DPPH• RS activity. 
Table 2. Computed parameters (in $\mathrm{kcal} / \mathrm{mol}$ ) of $\mathrm{O}-\mathrm{H}$ bond dissociation energy in the gas $(\mathrm{g}$ ) and aqueous (aq) phases $\left(\mathrm{BDE}_{\mathrm{g}}, \mathrm{BDFE}_{\mathrm{aq}}\right)$ and the electron donating capacity (ionization potential and electron transfer free energy) $\left(\mathrm{IP}_{\mathrm{g}}, \mathrm{ETFE}_{\mathrm{aq}}\right)$ as well as acidity $\left(\mathrm{pK}_{\mathrm{a}}\right)$ of studied derivatives with unsubstituted pyrazine ring $\mathrm{A}$ (a) and corresponding chalcones, the guaiacyl derivatives $4 \mathrm{c}$ and $4 \mathrm{e}$ in addition to well-known antioxidants.

\begin{tabular}{ccccccc}
\hline Compound & $\mathbf{B D E}_{\mathbf{g}}$ & $\mathbf{I P}_{\mathbf{g}}$ & $\mathbf{B D F E}_{\mathbf{a q}}$ & $\mathbf{I F E}_{\mathbf{a q}}$ & $\mathbf{p K}_{\mathbf{a}}$ & $\mathbf{E T F E}_{\mathbf{a q}}$ \\
\hline 1 & 84.9 & 188 & 85.7 & 107.8 & 10.9 & 77.5 \\
$1 \mathrm{a}$ & 85.7 & 192.5 & 82.9 & 106.9 & 8.4 & 78.1 \\
2 & 88.5 & 191.2 & 86.5 & 108.9 & 13.2 & 75.2 \\
$2 \mathrm{a}$ & 88.5 & 192 & 87.5 & 108.7 & 13.4 & 75.9 \\
3 & 85.2 & 184.6 & 83.9 & 103.5 & 11.1 & 77.5 \\
$3 \mathrm{a}$ & 85.4 & 188.4 & 84.4 & 102.8 & 10.7 & 76.6 \\
4 & 86 & 177.5 & 84.7 & 99.3 & 12.8 & 73.9 \\
$4 \mathrm{a}$ & 85.8 & 178.4 & 84.8 & 99.2 & 12.0 & 75.2 \\
$4 \mathrm{c}$ & 85.7 & 176.4 & 84.2 & 97.8 & 11.8 & 74.8 \\
$4 \mathrm{e}$ & 85.9 & 176.4 & 86.4 & 99.2 & 13.3 & 74.9 \\
Apigenin (4'-OH) & 86.7 & 176.7 & 85.3 & 100.6 & 11.4 & 76.4 \\
Quercetin (4'-OH) & 79.3 & 176 & 80.2 & 98.8 & 8.9 & 74.8 \\
Vitamin C & 78.2 & 206.8 & 77.6 & 109 & 3.7 & 79.4 \\
\hline
\end{tabular}

\subsection{Effects of Selected Compounds on the Growth of THP-1 Cells Pre- or Post-Treated with $\mathrm{H}_{2} \mathrm{O}_{2}$}

The three compounds $4 \mathrm{a}$, 4c and 4e which were non-toxic for THP- 1 cells after overnight incubation and had demonstrated RS activity, were further tested for the antioxidative activity using THP-1 based cellular assay (Figure 2). They were added at their DPPH• RS IC I0 $_{50}$ concentrations (Table 1) to THP-1 cells 30 min before or after $\mathrm{H}_{2} \mathrm{O}_{2}$. The aim of this part of the study was to see if the compounds may alter cytotoxic and growth suppressing effects of $\mathrm{H}_{2} \mathrm{O}_{2}$ as was recently described for antioxidative 1,4-dihydropyridine derivatives [42]. Although the three compounds are structurally similar (Figure 3), their effects on the growth of THP-1 cells through a four day period without or with the presence of $\mathrm{H}_{2} \mathrm{O}_{2}$ oxidant, were different.

Considering antiproliferative effects of the pure substances, only $4 \mathrm{e}$ had no considerable effects on the growth of the THP- 1 cells during a longer time period (Figure 2a). In the experiments with $\mathrm{H}_{2} \mathrm{O}_{2}$, all three compounds attenuated pro-oxidative activity of $\mathrm{H}_{2} \mathrm{O}_{2}$, except 4a when it was added to the cell culture after $\mathrm{H}_{2} \mathrm{O}_{2}$ (Figure $2 b$ ). The attenuating effects followed a similar pattern, but with a difference in magnitude. The lowest effect against cytotoxic activity of $\mathrm{H}_{2} \mathrm{O}_{2}$ was observed with $4 \mathrm{a}$, which is the weakest radical scavenger and the least lipophilic molecule among them (Table 1). The most efficient reduction of cytotoxic effect of $\mathrm{H}_{2} \mathrm{O}_{2}$ was achieved with $4 \mathrm{c}$ when it was added before $\mathrm{H}_{2} \mathrm{O}_{2}$ (Figure 2c), possibly due to its strongest RS capacity. In this treatment, the number of the THP-1 cells did not decrease at all and remained higher than the respective values for the cells treated only with $\mathrm{H}_{2} \mathrm{O}_{2}$ during whole experiment. THP-1 cells in all cases (b)-(d) start to recover after initial damage at $48 \mathrm{~h}$ point, but the extent of their recovery was considerably greater in the case of cells treated with the compounds $4 \mathrm{c}$ and $4 \mathrm{e}$.

Stronger antioxidative and cellular growth recovery effects of $4 \mathrm{c}$ and $4 \mathrm{e}$ as compared to $4 \mathrm{a}$, may be associated with their higher RS capacity and additionally with their greater lipophilic character which may enable more extensive uptake of these compounds by THP-1 cells (Table 1, Figure 3) [43]. The alkyl isopropyl and isobutyl R1 substituents significantly increase molecular lipophilicity of 4c and 4e as compared with unsubstituted analog 4a (Table 1).

The three guaiacyl-like derivatives as well as all other studied derivatives satisfy the Lipinski rule of five (Table S1). They are neutral molecules at pH 7.4 (except 1a, Table 2), moderately soluble in water and of moderate lipophilicity (Table S1). They are also not predicted to be substrates of the drug efflux pump P-glycoprotein. Thus, these alkyl-substituted pyrazine analogs of chalcones are expected to pass through cellular membranes including those of intestinal epithelial cells. None of 
the studied compounds are expected to cause mutagenic or tumorigenic effects (Table S1). However, as $\alpha, \beta$-unsaturated carbonyls, these derivatives may also react as Michael acceptors with reactive sulfhydryl groups of glutathione or cysteine amino acid residues of proteins. Such modifications of biomolecules are associated with an induction of the transcription of phase 2 enzymes and elevation of glutathione. These are major protective cellular responses against toxic and carcinogenic substances and may also contribute to the observed antioxidant cellular effects of considered compounds [16,37]. The direct RS activity that the compounds contribute to the observed cellular effects is indicated through the greater attenuation of $\mathrm{H}_{2} \mathrm{O}_{2}$ effects by the stronger radical scavengers $4 \mathrm{c}$ and $4 \mathrm{e}$ in the period up to $48 \mathrm{~h}$ (Figure 2). However, the greater recovery effects after $48 \mathrm{~h}$ in the case of THP-1 cells treated with these two compounds may suggest their bifunctional antioxidant role. After a long treatment, $4 \mathrm{c}$ and 4e may exert their antioxidant activity through the activation of the Kelch-like ECH-associated protein 1 (Keap1)/ Nuclear factor erythroid 2-related factor 2 (Nrf2) pathway. Some chalcones and chalcone-like derivatives have already been found to activate the Keap1/Nrf2 antioxidant response element (ARE) pathway through a Michael addition to the cysteine residues of Keap1, which is a redox sensor and negative regulator of $\mathrm{Nrf} 2[44,45]$.
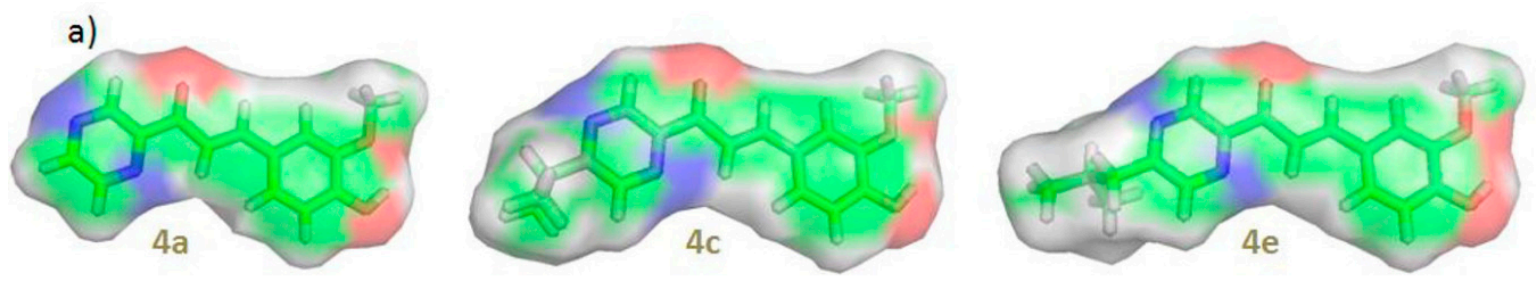

b)

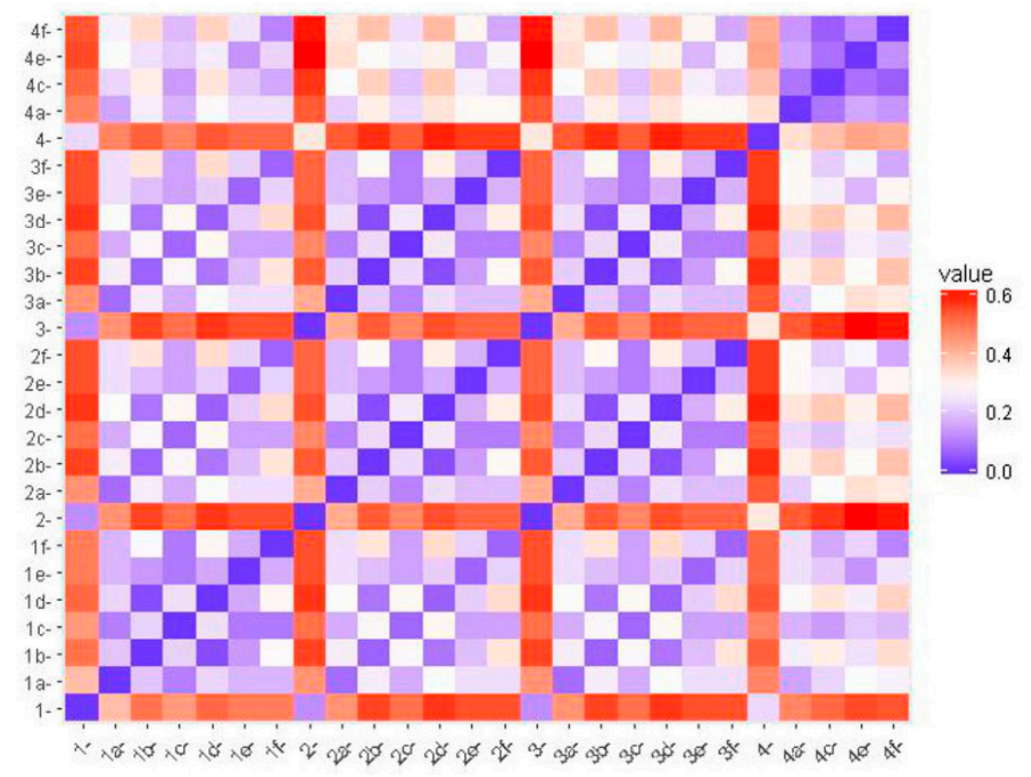

Figure 3. (a) Equilibrium ground-state structures (M052X/6-311++ $\mathrm{G}^{* *}$ ) with a Connolly surface (white parts correspond to nonpolar surface area) of the radical scavengers 4a, 4c and 4e; (b) Clustering of 26 compounds (Table 1) according to their structural similarity (more blue/red-more similar/dissimilar compounds).

\section{Conclusions}

The chalcone skeleton is a privileged scaffold in medicinal chemistry [1,2]. Many chalcone derivatives have shown biological activities (anti-infective, anticancer, anti-inflammatory) that may be associated with their antioxidant efficiency [11]. By applying the efficient and relatively inexpensive in vitro-in silico screening cascade, we determined antioxidant profiles for the set of non-cytotoxic pyrazine analogs of chalcones and analyzed them in terms of calculated RS parameters and molecular properties. Only derivatives $4 \mathrm{a}, 4 \mathrm{c}$ and $4 \mathrm{e}$ with a monomethylated catechol group in the ring B had 
DPPH• RS activity (Table 1) [15]. According to the quantum-chemical modeling, their RS mechanism corresponds to the two-step single electron transfer followed by proton transfer (SET-PT) pathway (Table 2). At the cellular level, the extent of attenuating effects against pro-oxidant $\mathrm{H}_{2} \mathrm{O}_{2}$, observed for radical scavengers $4 \mathrm{a}, 4 \mathrm{c}$ and $4 \mathrm{e}$ (Figure 2) were in agreement with their relative RS capacities and molecular lipophilicity $(\operatorname{cog} \mathrm{P})$ and depend also on the redox status of the cell. The screening cascade combining in vitro assays with proper in silico methods provided the efficient platform for identification and initial characterization of antioxidant properties of the studied compounds.

Supplementary Materials: The following are available online at http://www.mdpi.com/2076-3921/8/4/90/s1, Table S1. SMILES, simple structural and physicochemical properties as well as toxicity risk alerts calculated by SwissADME and DataWarrior (DW); and DFT equilibrium conformations in the sdf format.

Author Contributions: Conceptualization, N.Ž. and L.S.; compounds synthesis and provider, M.K.-C.; investigation, cells cultures, MTS and radical scavenging analysis, M.M. and D.V.; cellular antioxidative assay, T.H.; in silico analysis, V.S.; writing—original draft preparation, V.S., M.M., M.K.C.; review and editing, D.V., N.Ž. and L.S.

Funding: This research was funded by the Center of Excellence for Reproductive and Regenerative Medicine (KK.01.1.1.01, Croatia) and the research program Development and Study of Drugs Progress Q42 (Charles University, Prague, Czech Republic).

Acknowledgments: The authors are grateful to Veronika Opletalová for the design of the compounds and Koraljka Gall Trošelj for scientific and linguistic suggestions. The Croatian authors are thankful to the University Computing Centre SRCE for supporting the computational cluster Isabella (http://www.srce.unizg.hr/en/usluge/ isabella-cluster).

Conflicts of Interest: The authors declare no conflicts of interest.

\section{References}

1. Sahu, N.K.; Balbhadra, S.S.; Choudhary, J.; Kohli, D.V. Exploring pharmacological significance of chalcone scaffold: A review. Curr. Med. Chem. 2012, 19, 209-225. [CrossRef] [PubMed]

2. Gomes, M.N.; Muratov, E.N.; Pereira, M.; Peixoto, J.C.; Rosseto, L.P.; Cravo, P.V.L.; Andrade, C.H.; Neves, B.J. Chalcone Derivatives: Promising starting points for drug design. Molecules 2017, 22, 1210. [CrossRef] [PubMed]

3. Ritter, M.; Martins, R.M.; Dias, D.; Pereira, C.M.P. Recent advances on the synthesis of chalcone with antimicrobial activities: A brief review. Lett. Org. Chem. 2014, 11, 498-508. [CrossRef]

4. Mahapatra, D.K.; Bharti, S.K.; Asati, V. Chalcone derivatives: Anti-inflammatory potential and molecular targets perspectives. Curr. Top. Med. Chem. 2017, 17, 3146-3169. [CrossRef]

5. Sharma, R.; Kumar, R.; Kodwani, R.; Kapoor, S.; Khar, A.; Bansal, R.; Khurana, S.; Singh, S.; Thomas, J.; Roy, B.; et al. A review on mechanism of anti-tumor activity of chalcones. Anticancer Agents Med. Chem. 2016, 16, 200-211. [CrossRef]

6. Opletalová, V.; Hartl, J.; Patel, A.; Palát, K.; Buchta, V. Ring substituted 3-phenyl-1-(2-pyrazinyl)-2propen-1-ones as potential photosynthesis-inhibiting, antifungal and antimycobacterial agents. Farmaco 2002, 57, 135-144. [CrossRef]

7. Chlupáčová, M.; Opletalová, V.; Kuneš, J.; Silva, L.; Buchta, V.; Dušková, L.; Král'ová, K. Synthesis and biological evaluation of some ring-substituted (E)-3-aryl-1-pyrazin-2-ylprop-2-en-1-ones. Folia Pharm. Univ. Carol. 2005, 32, 31-43.

8. Kucerova-Chlupacova, M.; Kunes, J.; Buchta, V.; Vejsova, M.; Opletalova, V. Novel pyrazine analogs of chalcone: Synthesis and evaluation of their antifungal and antimycobacterial activity. Molecules 2015, 20, 1104-1117. [CrossRef]

9. Syam, S.; Abdelwahab, S.I.; Al-Mamary, M.A.; Mohan, S. Synthesis of chalcones with anticancer activities. Molecules 2012, 17, 6179-6195. [CrossRef]

10. Karthikeyan, C.; Narayana Moorthy, N.S.H.; Ramasamy, S.; Vanam, U.; Manivannan, E.; Karunagaran, D.; Trivedi, P. Advances in chalcones with anticancer activity. Recent Pat. Anticancer Drug Discov. 2015, 10, 97-115. [CrossRef] [PubMed]

11. Mahapatra, D.K.; Bharti, S.K.; Asati, V. Anti-cancer chalcone: Structural and molecular target perspectives. Eur. J. Med. Chem. 2015, 98, 69-114. [CrossRef] [PubMed] 
12. Katsori, A.M.; Hadjipavlou-Litina, D. Recent progress in therapeutic applications of chalcones. Expert Opin. Ther. Pat. 2011, 21, 1575-1596. [CrossRef] [PubMed]

13. Forejtníková, H.; Lunerová, K.; Kubínová, R.; Jankovská, D.; Marek, R.; Kareš, R.; Suchý, V.; Vondráček, J.; Machala, M. Chemoprotective and toxic potentials of synthetic and natural chalcones and dihydrochalcones in vitro. Toxicology 2005, 208, 81-93. [CrossRef] [PubMed]

14. Gerhäuser, C. Beer constituents as potential cancer chemopreventive agents. Eur. J. Med. Chem. 2005, 41, 1941-1954. [CrossRef] [PubMed]

15. Batovska, D.I.; Todorova, I.T. Trends in utilization of the pharmacological potential of chalcones. Curr. Clin. Pharmacol. 2010, 5, 1-29. [CrossRef] [PubMed]

16. Dimmock, J.R.; Elias, D.W.; Beazely, M.A.; Kandepu, N.M. Bioactivities of chalcones. Curr. Med. Chem. 1999, 6, 1125-1149. [PubMed]

17. Sander, T.; Freyss, J.; von Korff, M.; Rufener, C. DataWarrior: An open-source program for chemistry aware data visualization and analysis. J. Chem. Inf. Model. 2015, 55, 460-473. [CrossRef] [PubMed]

18. Machala, M.; Kubínová, R.; Hořavová, P.; Suchý, V. Chemoprotective potentials of homoisoflavonoids and chalcones of Dracaena cinnabari: Modulations of drug-metabolizing enzymes and antioxidant activity. Phytother. Res. 2001, 15, 114-118. [CrossRef] [PubMed]

19. Kucerova-Chlupacova, M.; Dosedel, M.; Kunes, J.; Soltesova-Prnova, M.; Majekova, M.; Stefek, M. Chalcones and their pyrazine analogs: Synthesis, inhibition of aldose reductase, antioxidant activity, and molecular docking study. Mon. Chem. 2018, 149, 921-929. [CrossRef]

20. Srivastava, S.K.; Ramana, K.V.; Bhatnagar, A. Role of aldose reductase and oxidative damage in diabetes and the consequent potential for therapeutic options. Endocr. Rev. 2005, 26, 380-392. [CrossRef]

21. Go, M.L.; Wu, X.; Liu, X.L. Chalcones: An update on cytotoxic and chemopreventive properties. Curr. Med. Chem. 2005, 12, 481-499. [CrossRef]

22. Rossi, M.; Caruso, F.; Crespi, E.J.; Pedersen, J.Z.; Nakano, G.; Duong, M.; McKee, C.; Lee, S.; Jiwrajka, M.; Caldwell, C.; et al. Probing antioxidant activity of 2'-hydroxychalcones: Crystal and molecular structures, in vitro antiproliferative studies and in vivo effects on glucose regulation. Biochimie 2013, 95, 1954-1963. [CrossRef] [PubMed]

23. Cheng, Z.J.; Kuo, S.C.; Chan, S.C.; Ko, F.N.; Teng, C.M. Antioxidant properties of butein isolated from Dalbergia odorifera. Biochim. Biphys. Acta 1998, 1392, 291-299. [CrossRef]

24. Hatano, T.; Takagi, M.; Ito, H.; Yoshida, T. Phenolic constituents of liquorice. VII. A new chalcone with potent radical scavenging activity and accompanying phenolics from liquorice. Chem. Pharm. Bull. 1997, 45, 1485-1492. [CrossRef]

25. Ni, L.; Meng, C.Q.; Sikorski, J. Recent advance in therapeutic chalcones. Expert Opin. Ther. Pat. 2004, 14, 1669-1691. [CrossRef]

26. Rubelj, I.; Stepanić, V.; Jelić, D.; Škrobot Vidaček, N.; Ćukušić Kalajžić, A.; Ivanković, M.; Nujić, K.; Matijašić, M.; Verbanac, D. Tebrophen—An old polyphenol drug with anticancer potential. Molecules 2012, 17, 7864-7886. [CrossRef] [PubMed]

27. Blois, M.S. Antioxidant determinations by the use of a stable free radical. Nature 1958, 181, 1199-1200. [CrossRef]

28. Cesar, V.; Jozić, I.; Begović, L.; Vuković, T.; Mlinarić, S.; Lepeduš, H.; Borović Šunjić, S.; Žarković, N. Cell-type-specific modulation of hydrogen peroxide cytotoxicity and 4-hydroxynonenal binding to human cellular proteins in vitro by antioxidant Aloe vera extract. Antioxidants 2018, 7, 125. [CrossRef] [PubMed]

29. Daina, A.; Michielin, O.; Zoete, V. SwissADME: A free web tool to evaluate pharmacokinetics, drug-likeness and medicinal chemistry friendliness of small molecules. Sci. Rep. 2017, 7, 42717. [CrossRef]

30. The R Project for Statistical Computing. Available online: https://www.r-project.org/ (accessed on 28 January 2019).

31. Durant, J.L.; Leland, B.A.; Henry, D.R.; Nourse, J.G. Reoptimization of MDL keys for use in drug discovery. J. Chem. Inf. Comput. Sci. 2002, 42, 1273-1280. [CrossRef]

32. Stepanić, V.; Gall Trošelj, K.; Lučić, B.; Marković, Z.; Amić, D. Bond dissociation free energy as a general parameter for flavonoid radical scavenging activity. Food Chem. 2013, 141, 1562-1570. [CrossRef] [PubMed]

33. Zhao, Y.; Schultz, N.E.; Truhlar, D.G. Design of density functionals by combining the method of constraint satisfaction with parametrization for thermochemistry, thermochemical kinetics, and noncovalent interactions. J. Chem. Theory Comput. 2006, 2, 364-382. [CrossRef] 
34. Frisch, M.J.; Trucks, G.W.; Schlegel, H.B.; Scuseria, G.E.; Robb, M.A.; Cheeseman, J.R.; Scalmani, G.; Barone, V.; Mennucci, B.; Petersson, G.; et al. Gaussian 09 Revision D.01; Gaussian, Inc.: Wallingford, CT, USA, 2013.

35. Marenich, A.V.; Cramer, C.J.; Truhlar, D.G. Universal solvation model based on solute electron density and a continuum model of the solvent defined by the bulk dielectric constant and atomic surface tensions. J. Phys. Chem. B 2009, 113, 6378-6396. [CrossRef]

36. Mosmann, T. Rapid colorimetric assay for cellular growth and survival: Application to proliferation and cytotoxicity assays. J. Immunol. Methods 1983, 65, 55-63. [CrossRef]

37. Dinkova-Kostova, A.T.; Massiah, M.A.; Bozak, R.E.; Hicks, R.J.; Talalay, P. Potency of Michael reaction acceptors as inducers of enzymes that protect against carcinogenesis depends on their reactivity with sulfhydryl groups. Proc. Natl. Acad. Sci. USA 2001, 98, 3404-3409. [CrossRef] [PubMed]

38. Ohkatsu, Y.; Satoh, T. Antioxidant and photo-antioxidant activities of chalcone derivatives. J. Jpn. Petrol. Inst. 2008, 51, 298-308. [CrossRef]

39. Qian, A.P.; Shang, Y.J.; Teng, Q.F.; Chang, J.; Fan, G.J.; Wei, X.; Li, R.R.; Li, H.P.; Yao, X.J.; Dai, F.; et al. Hydroxychalxones as potent antioxidants: Structure-activity relationship analysis and mechanism considerations. Food Chem. 2011, 126, 214-248. [CrossRef]

40. Cai, Y.Z.; Sun, M.; Xing, J.; Luo, Q.; Corke, H. Structure-RS activity relationship of phenolic compounds from traditional Chinese medicinal plants. Life Sci. 2006, 78, 2872-2888. [CrossRef]

41. Nenadis, N.; Wang, L.F.; Tsimidou, M.Z.; Zhang, H.Y. Radical scavenging potential of phenolic compounds encountered in O. europaea products as indicated by calculation of bond dissociation enthalpy and ionization potential values. J. Agric. Food Chem. 2005, 53, 295-299. [CrossRef]

42. Milkovic, L.; Vukovic, T.; Zarkovic, N.; Tatzber, F.; Bisenieks, E.; Kalme, Z.; Bruvere, I.; Ogle, Z.; Poikans, J.; Velena, A.; et al. Antioxidative 1,4-dihydropyridine derivatives modulate oxidative stress and growth of human osteoblast-like cells in vitro. Antioxidants 2018, 7, 123. [CrossRef]

43. Kraljević Gazivoda, T.; Harej, A.; Sedić, M.; Pavelić Kraljević, S.; Stepanić, V.; Drenjančević, D.; Talapko, J.; Raić-Malić, S. Synthesis, in vitro anticancer and antibacterial activities and in silico studies of new 4-substituted 1,2,3-triazole-coumarin hybrids. Eur. J. Med. Chem. 2016, 124, 794-808. [CrossRef] [PubMed]

44. De Freitas Silva, M.; Pruccoli, L.; Morroni, F.; Sita, G.; Seghetti, F.; Viegas, C.; Tarozzi, A. The Keap1/Nrf2-ARE pathway as a pharmacological target for chalcones. Molecules 2018, 23, 1803. [CrossRef] [PubMed]

45. Lounsbury, N.; Mateo, G.; Jones, B.; Papaiahgari, S.; Thimmulappa, R.K.; Teijaro, C.; Gordon, J.; Korzekwa, K.; Ye, M.; Allaway, G.; et al. Heterocyclic chalcone activators of nuclear factor (erythroid-derived 2)-like 2 (Nrf2) with improved in vivo efficacy. Bioorg. Med. Chem. 2015, 23, 5352-5359. [CrossRef] [PubMed] 